\title{
The Effect of Perception and Social Environment on Decision Making to be a Debtor of BPR Pijer Podi Kekelengen-Simpang Selayang Medan Branch with Motivation as Intervening Variables
}

\author{
Retno Nela Simanjuntak ${ }^{1}$, Amrin Fauzi ${ }^{2}$, Beby Karina Fawzeea Sembiring ${ }^{2}$ \\ ${ }^{1,2}$ Master of Management on Postgraduate School of University of Sumatera Utara \\ Corresponding Author: Retno Nela Simanjuntak
}

\section{ABSTRACT}

Consumer decision making is a basic psychological process that plays an important role in understanding how consumers actually decide something to use or buy. Decision making for customers to become debtors is influenced by several internal and external factors and in this study, perception, social environment and motivation factors were selected as factors that could influence decision making to become a debtor or loan customer at BPR Pijer Podi Kekelengen Branch Simpang Selayang Medan. The formulation of the problem is whether there is an influence of perceptions and the social environment on decision making to become a loan customer of the BPR Pijer Podi Kekelengen Simpang Selayang Medan Branch, either directly or indirectly through motivation. The hypothesis in this study is that the perception and social environment have a significant effect on decision making to become a loan customer at the BPR Pijer Podi Kekelengen Branch of Simpang Selayang Medan, either directly or indirectly through motivation. This study used a survey approach. Methods of data collection are carried out through interviews, documentation and questionnaires. The number of samples in this study were 90 people who were determined by accidental sampling. Hypothesis testing using Structural Equation Model (SEM) analysis is intended to determine the effect of independent variables on the dependent variable through or without intervening variables on the basis of decision making seen from the value of p> $0.05 \mathrm{H} 0$ is accepted and $\mathrm{Ha}$ is rejected or $\mathrm{p}$
\end{abstract}

$<0.05 \mathrm{H} 0$ is rejected. and Ha accepted. The test results show that the perception and social environment directly have a significant effect on debtor decision making. In this study, the motivation variable does not act as an intervening variable that mediates the influence between perceptions and the social environment on decision making to become a loan customer. Social Environment variable is the variable that has the greatest influence on decision making with a coefficient value of 0.461 .

Keywords: perception, social environment, motivation, decision making

\section{BACKGROUND}

In an era of disruption like this, it certainly makes banks more challenged to create strategies in an effort to increase the motivation of prospective customers. Every bank tries to provide loan or credit products with various facilities, especially interest rates and ease of procedure, even accompanied by prizes to attract public interest so that they decide to become a customer of the bank. Competition between banks is increasingly trying to find out the characteristics of the needs of prospective customers, even though the prospective customer already has his own criteria in choosing the bank he wants to get a loan.

Motivation to become a loan customer is influenced by several factors such as ease of procedure, bank interest rates and gifts offered to make customers 
Retno Nela Simanjuntak et.al. The effect of perception and social environment on decision making to be a debtor of BPR Pijer Podi Kekelengen-Simpang Selayang Medan branch with motivation as intervening variables.

want to borrow from the bank. In taking credit, customers can be influenced by various factors, both internal and external factors. Both of these factors can influence a customer's decision to take a loan. Kotler (2016) further explains that what influences customers in making a decision to take credit consist of personal, psychological, social and cultural factors. This cultural factor is very broad in nature, and involves all aspects of human life. Culture is a complex symbol and fact, created by humans, passed down from generation to generation as determinants and regulators of human behavior in existing societies.

Based on the theory above, it shows that consumer behavior in choosing banking services, especially for obtaining loan funds, is not consistent, but is caused by many factors. This is also experienced by customers of BPR Pijer Podi Kekelengen, Medan Simpang Selayang Branch, which is one of the banks with various types of loan products and facilities that continues to try to recruit as many customers as possible to achieve predetermined targets. BPR Pijer Podi Kekelengan Medan Simpang Selayang Branch must be able to compete in reaching customers or retain customers in the condition of the large number of products and facilities offered by its competing banks, both from the government and the private sector.

Table 1 Number of BPR Pijer Podi Kekelengen Loan Customers at Simpang Selayang Branch 2016 - 2019

\begin{tabular}{|l|l|l|}
\hline Year & Debtor & Amount (Rp.) \\
\hline 2016 & 1.026 & 15.283 .062 .884 \\
\hline 2017 & 1.024 & 20.407 .132 .275 \\
\hline 2018 & 901 & 19.272 .512 .019 \\
\hline 2019 & 880 & 19.665 .443 .785 \\
\hline
\end{tabular}

The table above show a decrease in the number of debtors each year, it can be seen that in 2018 and 2019 the decline was quite drastic. This shows that customers have their own criteria or determining factors that motivate them to borrow and finally choose and decide to become loan customers of the BPR Pijer Podi Kekelengan Branch of Simpang Selayang Medan.
By looking at the conditions of growth in lending that do not reach the predetermined target, it is necessary to have an appropriate marketing strategy to find opportunities or new customers and maintain existing customers, thus banks must also create new innovations regarding their products. superior products to add attractiveness to customers and potential customers. To create these new innovations, it is first necessary to conduct research on what factors influence customers in taking credit.

Based on the phenomenon that occurs, the researcher is interested in examining whether there is the influence of perception and the social environment on decision making to become a loan customer at the BPR Pijer Podi Kekelengan Branch of Simpang Selayang Medan with motivation as an intervening variable. Through these conditions, we want to know how the perceptions and social environment of these customers influence them through their motivation so that they decide to become loan customers of the BPR Pijer Podi Kekelengan Branch of Simpang Selayang Medan.

\section{Perception}

Consumer perception is a process that occurs as a result of stimuli received through the senses which makes a person choose, organize, and interpret so that it becomes a meaningful and complete picture of something. Recognition of an object, clearly, its movement, intensity and smell is a clue that affects perception. According to Sangaji and Sopiah (2013), perception is a process that arises as a result of sensation, in which the notion of sensation is the activity of feeling or the cause of a joyful emotional state. Sensation is also defined as the rapid response of our senses to basic stimuli such as light, color, and sound. This is what gives rise to perception.

\section{Social environment}

According to Peter and Olson (2013: 6), the social environment is all social 
Retno Nela Simanjuntak et.al. The effect of perception and social environment on decision making to be a debtor of BPR Pijer Podi Kekelengen-Simpang Selayang Medan branch with motivation as intervening variables.

interactions between communities, either directly, for example by discussing with a friend, or vicariously, namely observations about what other people are doing or wearing. Bintarto and Surastopo in Subagio (2019: 265) define the social environment as an environment where individuals interact, which has several aspects, namely social attitudes, psychological attitudes, spiritual attitudes, and so on.

\section{Motivation}

According to Robbins in Sangaji and Sopiah (2013: 154), motivation is the willingness to spend a high level of effort for organizational goals conditioned by the ability of that effort to meet several individual needs. Meanwhile, according to Sopiah (2013: 170) "motivation is a driving force that results in a member willing and willing to mobilize abilities in the form of expertise or skills, energy, and time to carry out various activities that are their responsibility and fulfill their obligations, in order to achieve goals and various predetermined organizational goals.

\section{Conceptual framework}

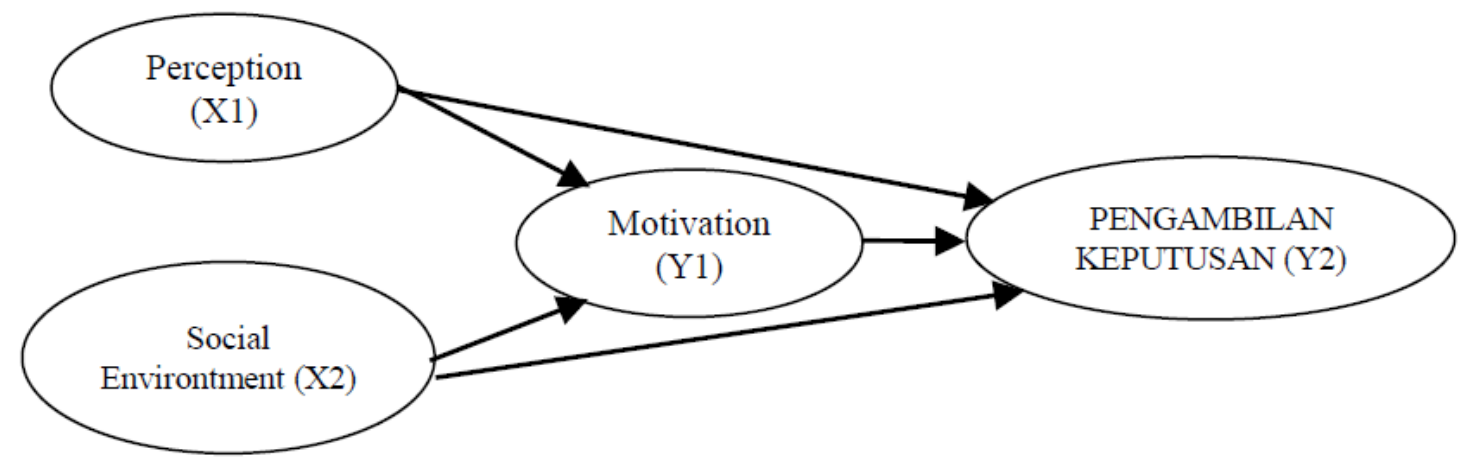

Figure 1 Conceptual Framework

\section{Hypothesis}

1. Perception has a positive effect on the motivation of loan customers at BPR Pijer Podi Kekelengan Branch of Simpang Selayang Medan.

2. Perception has a positive effect on decision making to become a loan customer at the BPR Pijer Podi Kekelengan Branch of Simpang Selayang Medan.

3. The social environment has a positive effect on the motivation of loan customers at the BPR Pijer Podi Kekelengan Branch of Simpang Selayang Medan.

4. The social environment has a positive effect on decision making to become a loan customer at the BPR Pijer Podi Kekelengan Branch of Simpang Selayang Medan.
5. Perceptions and the social environment have a positive effect on decision making to become a customer of the BPR Pijer Podi Kekelengan loan at Simpang Selayang Medan Branch through motivation.

\section{RESEARCH METHODS}

Based on the level of explanation of the problem under study, this research is an association research. The population in this study were all the customers of the BPR Pijer Podi Kekelengan Medan Branch of the Simpang Selayang Branch from January to December 2019 as many as 880 people. Samples were taken using the Slovin formula with accidental sampling technique of 90 people. Data collection using questionnaires and interviews. Testing data using the Structural Equation Model Partial Least Square (SEM-PLS) method. 
Retno Nela Simanjuntak et.al. The effect of perception and social environment on decision making to be a debtor of BPR Pijer Podi Kekelengen-Simpang Selayang Medan branch with motivation as intervening variables.

\section{RESULTS AND DISCUSSION}

Testing the Significance of Direct Influence

Table.2 Path Coefficient Value and P-Value

\begin{tabular}{|l|l|l|l|l|l|}
\hline & Original Sample (O) & Sample Mean (M) & Standard Deviation (STDEV) & T Statistics (|O/STDEV]) & P Values \\
\hline X1 -> Y1 & 0.395 & 0.397 & 0.096 & 4.113 & 0.000 \\
\hline $\mathbf{X 1}$-> Y2 & 0.418 & 0.423 & 0.090 & 4.621 & 0.000 \\
\hline $\mathbf{X 2}$-> Y1 & 0.380 & 0.386 & 0.095 & 3.989 & 0.000 \\
\hline $\mathbf{X 2}$-> Y2 & 0.461 & 0.461 & 0.096 & 4.825 & 0.000 \\
\hline Y1 >> Y2 & 0.330 & 0.337 & 0.113 & 2.916 & 0.004 \\
\hline
\end{tabular}

1. Perception has a positive effect on motivation, with a path coefficient of 0.395 and significant, with a P-value of $0.000<0.05$.

2. The social environment has a positive effect on motivation, with a path coefficient of 0.418 and significant, with a P-value of $0.000<0.05 .3$.

3. Perception has a positive effect on decision making, with a path coefficient of 0.380 and significant, with a P-value of $0.000<0.05$.

4. The social environment has a positive effect on decision making, with a path coefficient of 0.461 and significant, with a P-Values value of $0.000<0.05$.

5. Motivation has a positive effect on decision making, with a path coefficient of 0.330 and significant, with a P-Values value of $0.004<0.05$.

Table 3. The value of the coefficient of determination

\begin{tabular}{|l|l|}
\hline & R Square \\
\hline Motivation (Y1) & 0.427 \\
\hline Making Decision (Y2) & 0.612 \\
\hline
\end{tabular}

The coefficient of determination for the motivation variable is 0.676 , which means that the perception variable, social environment, is able to influence motivation by $42.7 \%$. The coefficient of determination of the decision making variable is 0.728 . This value can be interpreted that the variables of perception, social environment and motivation are able to influence decision making by $61.2 \%$.

\section{Testing the Significance of Indirect Effects}

Table 4. Path Coefficient Value and P-Value

\begin{tabular}{|l|l|l|l|l|l|}
\hline & $\begin{array}{l}\text { Original } \\
\text { Sample } \\
(\mathbf{O})\end{array}$ & $\begin{array}{l}\text { Sample } \\
\text { Mean } \\
(\mathbf{M})\end{array}$ & $\begin{array}{l}\text { Standard } \\
\text { Deviation } \\
\text { (STDEV) }\end{array}$ & $\begin{array}{l}\text { T Statistics } \\
(\mid \mathbf{O} / \text { STDEV|) }\end{array}$ & $\begin{array}{l}\text { P } \\
\text { Values }\end{array}$ \\
\hline Perception (X1) -> Motivation (Y1) -> Decision Making (Y2) & 0.131 & 0.135 & 0.061 & 2.129 & 0.034 \\
\hline $\begin{array}{l}\text { Social Environment (X2) -> Motivation (Y1) -> Decision } \\
\text { Making (Y2) }\end{array}$ & 0.126 & 0.129 & 0.054 & 2.343 & 0.020 \\
\hline
\end{tabular}

1. The indirect effect of perceptions on decision making, through motivation of 0.131 with a $\mathrm{P}$-Values value of 0.034 $<0.05$, it is concluded that the motivation variable is not significant in mediating the effect of perceptions on decision making, because the significant value of the direct effect is greater than the significant indirect effect.

2. The indirect effect of the social environment on decision making, through motivation of 0.126 with a $\mathrm{P}$ Values value of $0.020<0.05$, it is concluded that the motivation variable is not significant in mediating the influence of the social environment on decision making because the significant value of the direct effect is greater than the significant value indirect effect.

Based on the results of data analysis that has been carried out, information is obtained that customer perceptions have a significant effect on customer motivation, namely by a positive perception of BPR Pijer Podi Kekelengen Simpang Selayang Medan Branch and its loan products support the motivation that arises in customers to borrow so that they finally decide to become 
Retno Nela Simanjuntak et.al. The effect of perception and social environment on decision making to be a debtor of BPR Pijer Podi Kekelengen-Simpang Selayang Medan branch with motivation as intervening variables.

loan customers of BPR Pijer Podi Kekelengen, Simpang Selayang Medan Branch. This supports the analysis of respondents 'answers regarding perceptions, namely regarding respondents' perceptions regarding the quality of loan products at BPR Pijer Podi Kekelengen, Simpang Selayang Medan Branch where people strongly believe that the loan product of BPR Pijer Podi Kekelengen Branch Simpang Selayang Medan is of very good quality, thus motivating customers to lend money.

Customer perception has a significant effect on decision making to become a customer of this BPR. Debtors decide to borrow because they have a positive and good perception of BPR Pijer Podi Kekelengen Simpang Selayang Medan Branch. The social environment of the customer has a significant effect on decision making to become a customer of the BPR Pijer Podi Kekelengen loan at Simpang Selayang Medan Branch. The situation factors experienced by the customer, sufficient information available, information and suggestions from other people as well as outreach from the BPR Pijer Podi Kekelengen Branch of the Simpang Selayang Medan led the debtor to decide to become a loan customer of the BPR Pijer Podi Kekelengen Branch of the Simpang Selayang Medan.

This customer's social environment also has a significant effect on customer motivation, where the factors contained in this social environment variable are able to influence and support the customer's motivation to become a loan customer, especially regarding the motivation to build a business so that it requires a loan. It can be seen from the answers of respondents that the condition of customers who are generally traders, they are motivated to borrow a lot because they receive information from the socialization of Bank Podi that they can get financial assistance in the form of loans with easy terms and procedures and low interest to build a business or develop their business. .

\section{CONCLUSION}

1. Perception and social environment have a significant effect on the motivation of loan customers at BPR Pijer Podi Kekelengen Simpang Selayang Medan Branch with a probability value (p) $<0.05$.

2. Perception and social environment have a significant effect on decision making to become a customer of the BPR Pijer Podi Kekelengen loan at Simpang Selayang Medan Branch with a probability value $(\mathrm{p})<0.05$.

3. Motivation has a significant effect on decision making to become a loan customer at the BPR Pijer Podi Kekelengen Simpang Selayang Medan Branch with a probability value (p) $<0.05$.

4. Perception and social environment have a significant effect on decision making to become a customer of the BPR Pijer Podi Kekelengen loan at Simpang Selayang Medan Branch through customer motivation.

5. The effect of perceptions and the social environment is much greater directly on the decision to become a customer of the BPR Pijer Podi Kekelengen loan at Simpang Selayang Branch Medan, compared to the indirect effect of perception and the social environment on making decision.

\section{Acknowledgement: None}

\section{Conflict of Interest: None}

\section{Source of Funding: None}

\section{REFERENCES}

1. Adesoga, Adefulu dan Van Sheers Louise. 2016. Consumer Perceptions Of Banking Services:Factors For Bank's Preference. Journal Bussines. Vol 6 : hal.379

2. Arikunto, Suharsimi. 2014. Prosedur Penelitian. Jakarta : Rineka Cipta

3. Febriany, Wulan. 2012. Pengaruh Faktor Eksternal dan Internal dalam Perilaku Pemilihan Sistem Perbankan Terhadap 
Retno Nela Simanjuntak et.al. The effect of perception and social environment on decision making to be a debtor of BPR Pijer Podi Kekelengen-Simpang Selayang Medan branch with motivation as intervening variables.

Keputusan Menabung Nasabah di Bandung Tahun 2012. Tesis

4. Ghozali, Imam. 2014. Structural Equation Modelling, Metode Alternatif dengan Partial Least Square (PLS) Edisi 4. Semarang: Badan Penerbit Universitas Diponegoro

5. Griffin, Jill. 2015. Customer Loyalty, Menumbuhkan dan Mempertahankan Kesetiaan Pelanggan. Alih bahasa: Dwi Kartini Yahya, dkk Jakarta: Erlangga

6. aque, A., Osman J \& Ismail, A. 2009. Factor Influences Selection of Islamic Banking: A Study on Malaysian Customer Preferences. American Journal of Applied Sciences, Journal Bussines Vol 6 (5): 922928

7. Hawkins, Del. I., and David L. Mothersbaugh. 2013. Consumer Behavior: building marketing strategy eleventh edition Boston : Mc Graw-Hill

8. Jenny, Mercer. 2012. Psikologi Sosial. Jakarta:Erlangga

9. Kotler, Philip \& Keller, Kevin Lane. 2016. Marketing Management $15^{\text {th }}$ Edition. New Jersey :Prentice Hall

10. Fadila dan Lestari. 2013. Perilaku Konsumen. Palembang: Citra Bools Indonesia

11. Kotler, Philip \&Armstrong, Gary. 2014. Principles of Marketing 15thEdition. New Jersey : Prentice Hall

12. Lubus A, N dan Ganjang A, G. 2008. Analisis Faktor-faktor yang Mempengaruhi Keputusan Permintaan Kredit pada PT. Bank Tabungan Negara Cabang Medan. Jurnal Manajemen Bisnis. Vol.1.No.2

13. Lumban Gaol, Analia, dkk. 2016. Pengaruh Kualitas Produk Terhadap Tingkat Kepuasan Konsumen dan Loyalitas Konsumen (Survei pada Mahasiswa S1 Fakultas Ilmu Administrasi Tahun Akademik 2012/2013 Universitas Brawijaya yang Menggunakan Smartphone Samsung). Jurnal Administrasi Bisnis. Vol. 38 No. 1

14. Mokhlis , Safiek. 2009.Determinants of Choice Criteria in Malaysia's Retail Banking: An Analysis of Gender-Based Choice Decision. European Journal of Economics, Finance and Administrative Sciences. Vol.16

15. Mowen, dan Minor. 2012. Perilaku konsumen. Jakarta : erlangga
16. Nababan , Denisa Irawaty dan Haroni Doli Hamoraon. 2013. Analisis FaktorFaktor Yang Mempengaruhi Keputusan Masyarakat Kecamatan Medan Helvetia Dalam Memilih Lembaga Keuangan Sebagai Sumber Pendanaan. Jurnal Ekonomi dan Keuangan. Vol 1: hal 23

17. Patriana , Ela dan Nurismalatr. 2018. Analisis Faktor Penentu Keputusan Konsumen Muslim Dalammemilih Jasa Perbankan:Bank Syariah Vs Bank Konvensional. Jurnal Ekonomi dan Keuangan. Vol 3: hal 58-59

18. Peter, J. Paul dan Jerry C. Olson. 2013. Perilaku Konsumen dan Strategi Pemasaran. Jakarta: Erlangga

19. Priyatno. Duwi. 2014. SPSS 22 Pengolahan Data Terpraktis. Yogyakarta: CV Andi Offset

20. Rino, dkk. 2020. Perilaku Organisasi. Bandung: Refika Aditama

21. Sangaji, Etta Mamang dan Sopiah. 2013. Perilaku Konsumen. Yogyakarta: ANDI

22. Santoso, S. (2014). Statistik Parametrik Edisi Revisi. Jakarta: Elex Media Komputindo

23. Schiffman dan Kanuk. 2015. Consumer Behavior Edisi 11 Global Edition England: Pearson Education Limited

24. Setiadi, Nugroho. 2013. Perilaku Konsumen: Edisi Revisi. Jakarta : Kencana Predana Media Group

25. Sharma, R.K., \& Rao, S.A. 2010. Bank Selection Criteria Employed by MBA Students in Delhi: An Empirical Analysis. Journal of Business Studies, 1(2): 56-69.

26. Suarni, dkk. 2014. Analisis Faktor yang Mempengaruhi Keputusan Nasabah dalam Pengambilan Kredit pada LPD (Lembaga Prekreditan Desa) Desa Pakraman Manggissari. Jurnal Manajemen. Vol.4.No.1

27. Subagio. 2019. Pengaruh Lingkungan Sosial Terhadap Perilaku Konsumtif Mahasiswa Fakultas Pendidikan Olahraga Dan Kesehatan (Fpok) Ikip Mataram. Jurnal Ilmu Sosial dan Pendidikan. Vol 3: hal 265

28. Sugiyono. 2015. Metode Penelitian Pendidikan. Bandung: Alfabeta

29. Suliasa I, M, F, I Nyoman, dan I Made, A K. 2018. Analisis Faktor-faktor yang Mempengaruhi Keputusan Nasabah Kredit di Lembaga Perkreditan Desa-Desa 
Retno Nela Simanjuntak et.al. The effect of perception and social environment on decision making to be a debtor of BPR Pijer Podi Kekelengen-Simpang Selayang Medan branch with motivation as intervening variables.

Pakraman Tajun Buleleng. Jurnal Manajemen. Vol.5.No.1

30. Sumara, Ahmad Yopi . 2017. Analisis Faktor-Faktor Yang Mempengaruhi Keputusan Nasabah Muslim Untuk Memilih Bank Konvensional (Studi Pada Mahasiswa Fakultas Ekonomi Dan Bisnis Islam Uin Sunan Kalijaga). Tesis. Yogyakarta. Universitas Islam Negri Sunan Kalijaga

31. Sumarwan, Ujang. 2014. Perilaku Konsumen: Teori dan Penerapannya dalam Pemasaran. Bogor: Ghalia Indonesia

32. Sumarwan, Ujang, dkk. 2013. Riset Pemasaran dan Konsumen. Bogor: IPB Press

33. Sunyoto, Danang. 2013. Perilaku Konsumen: Panduan Riset Sederhana untuk Mengenali Konsumen. Jakarta: PT. Buku Seru

34. Suryani, Tatik. 2013. Perilaku Konsumen di Era Internet. Yogyakarta: Graha Ilmu.
35. Twentinio, Irenes. 2013. Persepsi Pelanggan Terhadap Pengguna Speedy Jaringan Broad Band Readr. Laporan Akhir. Palembang. Politeknik Negeri Sriwjaya

36. Wibowo. 2016. Perilaku dalam Organisasi. Jakarta: Rajawali Pers

37. Wiryaningtyasa, Dwi Perwitasari. 2016. Pengaruh Keputusan Nasabah dalam Pengambilan Kredit pada Bank Kredit Desa Kabupaten Jember. Jurnal Manajemen Bisnis Growth Vol. 14 No 2 : 54-55

How to cite this article: Simanjuntak RN, Fauzi A, Sembiring BKF. The effect of perception and social environment on decision making to be a debtor of BPR Pijer Podi Kekelengen-Simpang Selayang Medan branch with motivation as intervening variables. International Journal of Research and Review. 2021; 8(4): 446-452. DOI: https://doi.org/10.52403/ijrr.20210454 